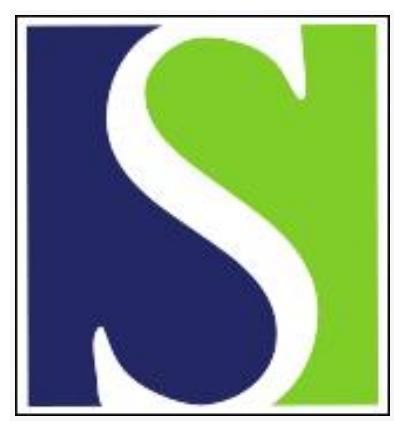

Scand J Work Environ Health 1986;12(4):293-295

https://doi.org/10.5271/sjweh.2138

Issue date: Aug 1986

Exposure conditions and Raynaud's phenomenon among riveters in the aircraft industry.

by Engstrom K, Dandanell R

The following article refers to this text: 2011;37(3):244-252

This article in PubMed: www.ncbi.nlm.nih.gov/pubmed/3775314

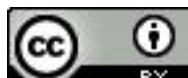




\title{
Exposure conditions and Raynaud's phenomenon among riveters in the aircraft industry
}

\author{
by Krister Engström, MD, Rolf Dandanell, MSc(Eng) ${ }^{1}$
}

\begin{abstract}
ENGSTRÖM K, DANDANELL R. Exposure conditions and Raynaud's phenomenon among riveters in the aircraft industry. Scand J Work Environ Health 12 (1986) 293-295. Riveters in the aircraft industry work daily with such vibrating tools as riveting hammers, bucking bars, drills, and rivet shavers. The main contribution of the vibration exposure comes from the riveting tools. Three hundred and forty riveters working at the Aircraft Division of Saab-Scania were investigated in respect to vibration exposure and symptoms of Raynaud's phenomenon. The employment time of this group varied from 1 to 44 years. Within the group, 86 riveters showed symptoms of Raynaud's phenomenon. The latency until first sign of injury ranged from 0 to 27 years with a median of almost 11 years. Although the exposure time for the riveting hammer was $1 \mathrm{~min}$ and the total tool time was $40 \mathrm{~min}$ per day, more than $50 \%$ of the riveters had symptoms of vibration-induced white finger (VWF) after more than 10 years of work. The guidelines of the International Organization for Standardization (ISO/DIS 5349) suggest a lesser risk, and they should therefore be complemented with additional criteria to be valid for percussion tools.
\end{abstract}

Key terms: impulse vibration, pneumatic hammer, risk assessment, riveters, riveting hammer.

The aircraft division of Saab-Scania in Sweden employs 340 riveters. The purpose of this study was to test whether the ISO/DIS 5349 (3) risk assessment for vibration-induced white finger (VWF) is applicable to these riveters.

The typical riveter is trained at Saab-Scania and usually stays in his job for many years. The riveting work is as follows: The riveter first drills a hole in the structure, then puts the rivet in the hole and closes up the rivet with a riveting hammer in one hand and a bucking bar in the other. In some situations two riveters are needed, one with the hammer and the other with the bucking bar. After the rivets are fixed in place, some of them have to be shaved. The technique has developed over the last 40 years. Automatic riveting and bonding have replaced some riveting. The new technique is handled by employees other than riveters. The drilling, riveting, and shaving operation is still the same as 40 years ago, and the tools have not changed significantly.

Three hundred and forty male riveters were interviewed. The following facts were noted: type of tool, daily exposure time, smoking habits, hand injuries, long-term medication (ergotamin, beta-blockers), diabetes, family history of Raynaud's phenomenon, blood pressure, and the presence of Raynaud's phenomenon or VWF.

Figure 1 shows the age distribution from 16 to 65 years.

In figure 2 the exposure time in years is shown. Due to changes in production half the population has been

\footnotetext{
1 Department of Occupational Health and Safety, SaabScania AB, Linköping, Sweden.
}

Reprint requests to: Dr K Engström, Department of Occupational Health and Safety, Saab-Scania AB, S-581 88 Linköping, Sweden. employed recently and has had a short exposure time. After 10 years of exposure $50 \%$ of the population had Raynaud's phenomenon. With an exposure time of up to 40 years one has to consider the "healthy worker effect," ie, some of the riveters who have developed VWF have turned to other jobs and are no longer in the examined population. Figure 3 shows the proportion of riveters with Raynaud's phenomenon in relation to the duration of exposure. After 20 years of riveting the risk of developing Raynaud's phenomenon is $50 \%$.

In the population of 340 riveters $50 \%$ was made up of smokers and snuffers, $1 \%$ had diabetes, $6 \%$ was on long-term medication, and $9 \%$ had a family history of Raynaud's phenomenon. These figures are lower than expected in the Swedish population. The

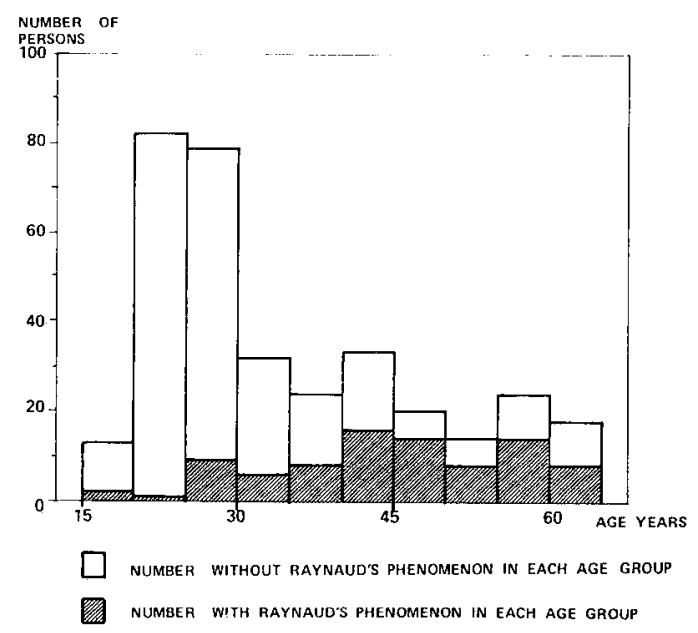

Figure 1. Age distribution of the 340 riveters ( 254 without and 86 with Raynaud's phenomenon). 


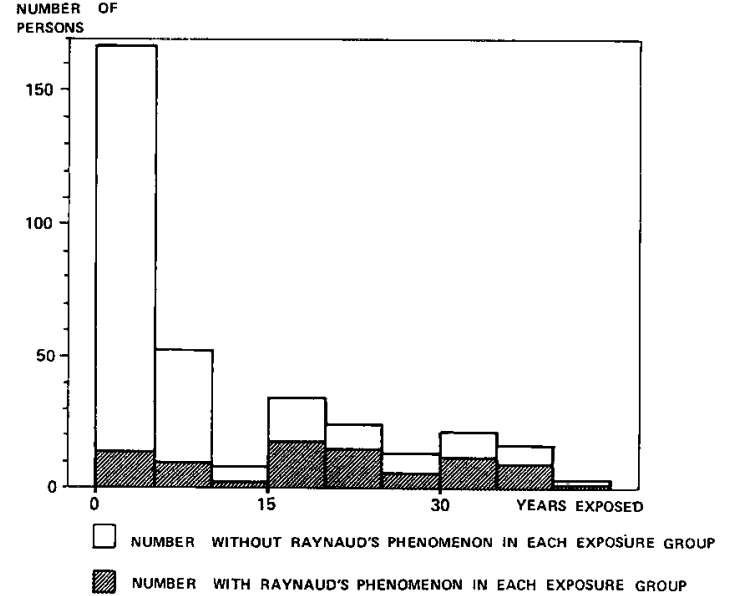

Figure 2. Length of exposure of the 340 riveters (254 without and 86 with Raynaud's phenomenon).

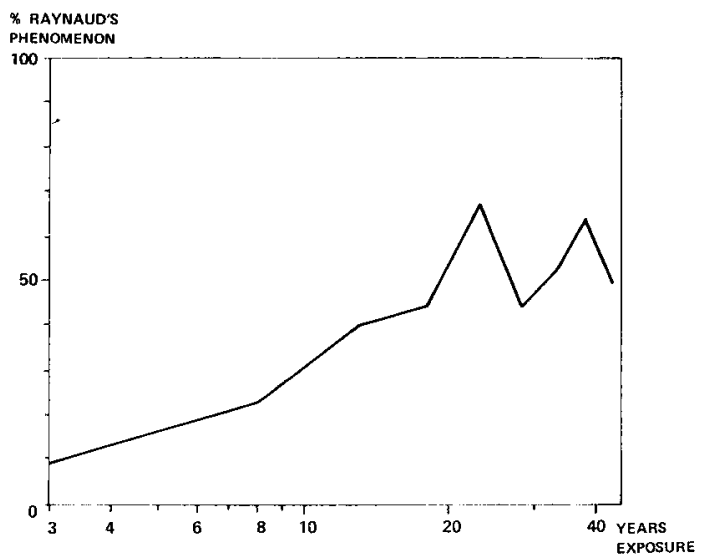

Figure 3. Proportion of riveters with Raynaud's phenomenon $(N=86$ ) in relation to the duration of exposure (total number of subjects $=340$ ).

Table 1. Severity of Raynaud's phenomenon among the 340 riveters according to the Taylor-Pelmear scale (5).

\begin{tabular}{lrrrrr}
\hline \multirow{2}{*}{ Stage } & \multicolumn{2}{c}{ Left hand } & & \multicolumn{2}{c}{ Right hand } \\
\cline { 2 - 3 } \cline { 6 - 6 } & $\mathrm{N}$ & $\%$ & & $\mathrm{~N}$ & $\%$ \\
\hline $00-0$ & 264 & 78 & 264 & 78 \\
1 & 48 & 14 & 43 & 13 \\
2 & 24 & 7 & 28 & 8 \\
3 & 3 & 1 & 4 & 1 \\
4 & 1 & 0.3 & 1 & 0.3 \\
\hline Total & 340 & 100 & 340 & 100 \\
\hline
\end{tabular}

Table 2. Variation in daily operating times among 340 riveters.

\begin{tabular}{lclc}
\hline Tool & $\begin{array}{c}25 \mathrm{th} \\
\text { percentile }\end{array}$ & Median & $\begin{array}{c}75 \mathrm{th} \\
\text { percentile }\end{array}$ \\
\hline Riveting hammer & $29 \mathrm{~s}$ & $43 \mathrm{~s}$ & $58 \mathrm{~s}$ \\
Rivet shaver & $14 \mathrm{~s}$ & $43 \mathrm{~s}$ & $158 \mathrm{~s}$ \\
Drill & $25 \mathrm{~min}$ & $30 \mathrm{~min}$ & $36 \mathrm{~min}$ \\
\hline
\end{tabular}

population of riveters was thus not biased by an increased number of vasospastic risk factors.

The severity of Raynaud's phenomenon among the riveters according to the Taylor-Pelmear (5) scale is shown in table 1. In order to avoid an overestimation of Raynaud's phenomenon during the interviews, stage 0 was transferred to stage $00=$ undamaged, and stage 1 was thus regarded as the first stage of injury. There were only a few riveters in stage 3 and 4 . No cold provocation test was performed to prove the outcome of the interviews.

\section{Vibration analysis of the tools}

The riveting hammer is characterized by relatively low levels of acceleration at low frequencies $(25-1000 \mathrm{~Hz})$ and high levels of acceleration at high frequencies (1 $000-10000 \mathrm{~Hz}$ ). The vibration characteristics of the bucking bar depend on its shape and weight, which can differ. There can be very high levels of acceleration at high frequencies due to resonance.

Two different measuring systems were used to measure the vibration from the riveting hammer and bucking bar. Up to $500-1000 \mathrm{~Hz}$, a displacement transducer (Bofors RLL-2) was used, and for vibration over $500 \mathrm{~Hz}$ a piezoelectric accelerometer was employed (Brüel \& Kjaer 8309).

The measuring and analyzing technique has been described by Dandanell \& Engström (2).

We analyzed the vibration from the riveting hammer and bucking bar with one-third octave-band analysis. If this analysis is to be comprehensive, the vibration must be at steady state and have a reasonable crest factor. None of these conditions prevail with percussion tools, but the analysis was carried out all the same according to ISO/DIS 5349 (3). For the hammer the weighted value was $10 \mathrm{~m} / \mathrm{s}^{2}$, and for the bucking bar it was $11 \mathrm{~m} / \mathrm{s}^{2}$.

The drill and the shaver were measured with an accelerometer (Brüel \& Kjaer 8309) during work: The vibration was analyzed according to ISO/DIS 5349 (1) with the one-third octave-band analysis. The calculated weighted value of the drill was $2 \mathrm{~m} / \mathrm{s}^{2}$, and that of the shaver was $5 \mathrm{~m} / \mathrm{s}^{2}$.

The daily exposure time, ie, the running time for the tools, was calculated in three ways. From the questionnaire we got the tool time per day per individual. With a pneumatic-electric chronometer attached to the tool, we could measure the operation time for each tool. From time studies, which are very realistic ways of measuring work moment in industry, we got the operation times. The operation times for riveting hammers, rivet shavers, and drills are shown in table 2 . The total tool operation time was about $33 \mathrm{~min} / \mathrm{d}$.

\section{Results}

According to ISO/DIS 5349 annex A (Guidelines for the evaluation of hand-transmitted vibration exposure) 


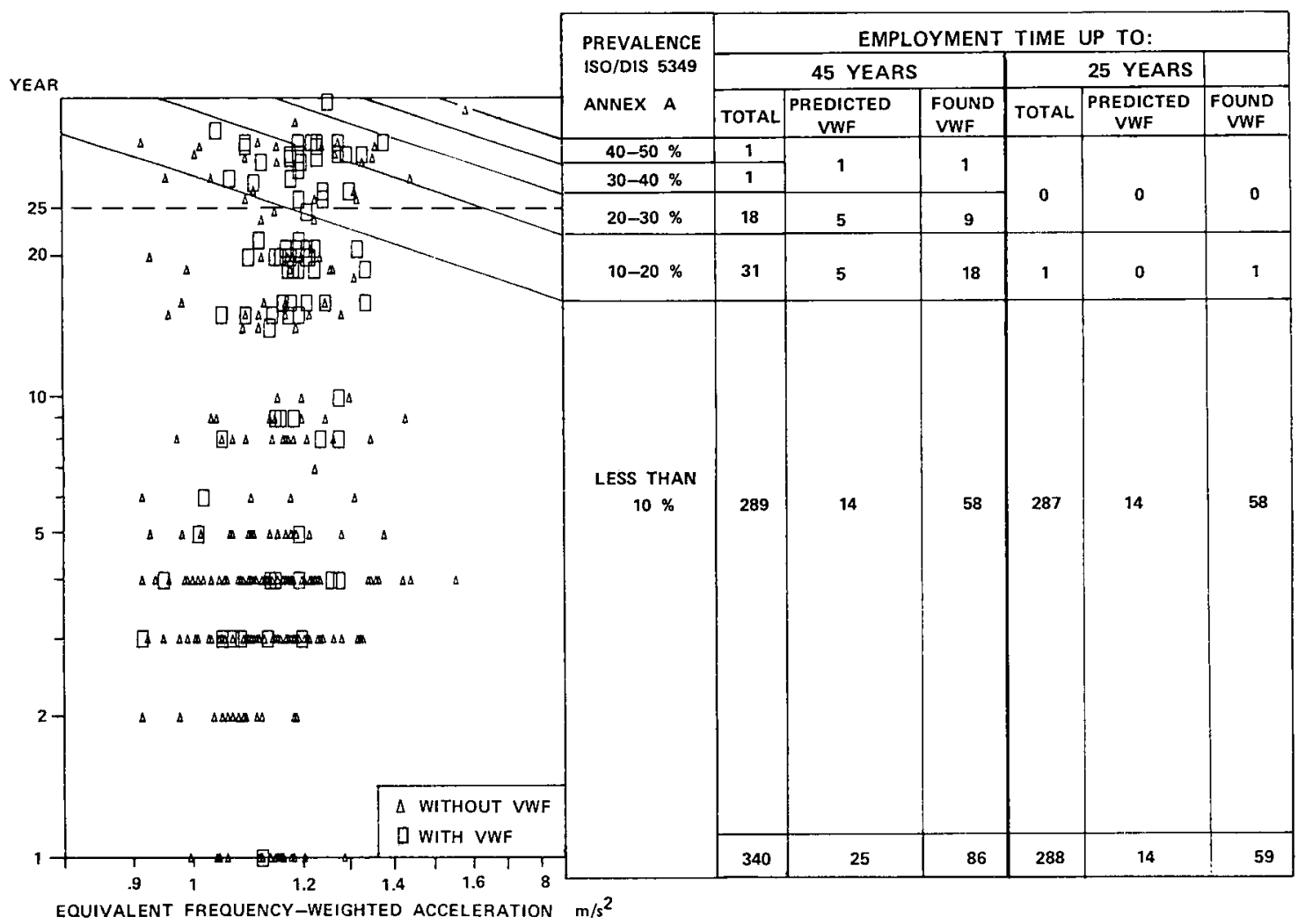

Figure 4. Risk of vibration-induced white finger (VWF) calculated for each of the 340 riveters.

(4) we can calculate the risk of VWF. As we have shown, we have the daily time exposure for the three operations drilling, riveting, and shaving and the weighted values of each of the three types of tools in meters per square seconds and the time of exposure in years. In figure 4 we have plotted each of the 340 riveters with their individual values.

The 254 triangles are riveters without Raynaud's phenomenon, and the 86 squares are riveters with Raynaud's phenomenon.

The annex $\mathrm{A}$ guidelines should not be used for more than 25 years of exposure. A calculation up to 25 years of exposure would result in 14 riveters with VWF out of 288 at risk. We found 59 with Raynaud's phenomenon in our population, the majority of which, in our opinion, was due to VWF.

\section{Conclusions}

In many other studies the risk assessments of ISO/DIS 5349 have proved to be realistic for rotating tools with sinusoidal vibration (3). We have two such tools, the drill and the shaver. By adding the exposure only from the drill and the shaver, we could calculate that the expected number of persons likely to develop VWF would be 14 . We found 59 persons with Raynaud's phenomenon. In the actual riveting work additional tools are used, the pneumatic riveting hammer and the bucking bar, which give off impact, shock-wave ac- celeration in a wide variety of frequencies. For onethird octave-band analysis to be comprehensive, the vibrations must be at steady state and have a reasonable crest factor, which is not the case in the use of the riveting tools. By using the one-third octave-band analysis for percussion tools, one probably underestimates the weighted values.

Our conclusion is that percussion hand tools call for a complement to the ISO/DIS 5349 regarding ways of measuring and analyzing technique and criteria.

\section{References}

1. Brammer AJ. Threshold limit for hand-arm vibration exposure throughout the workday. In: Brammer AJ, Taylor $\mathrm{W}$, ed. Vibration effects on the hand and arm in industry. John Wiley \& Sons, New York, NY 1982, pp 291-301.

2. Dandanell R, Engström $K$. Vibration from riveting tools in the frequency range $6 \mathrm{~Hz}-10 \mathrm{MHz}$ and Raynaud's phenomenon. Scand J Work Environ Health 12 (1986) $338-342$.

3. International Organization for Standardization. Guidelines for the measurement and assessment of human exposure to vibration transmitted to the hand. Geneva 1984. (ISO/DIS 5349.2-1984).

4. International Organization for Standardization. Guidelines for the measurement and assessment of human exposure to vibration transmitted to the hand: Annex A. Guidelines for the evaluation of hand-transmitted vibration exposure. Geneva 1984. (ISO/DIS 5349.2-1984).

5. Taylor W, Pelmear PL. Vibration white finger in industry. Academic Press, London 1975. 